Available online at GSC Online Press Directory

GSC Biological and Pharmaceutical Sciences

e-ISSN: 2581-3250, CODEN (USA): GBPSC2

Journal homepage: https://www.gsconlinepress.com/journals/gscbps

(CASE REPORT)

\title{
A 73-year-old man with pindborg tumor: A case report
}

\author{
Stefania Erra *, Valentina Caminiti, Michele De Luca, Alessia Frigeri and Luca Zambello \\ Surgical Pathology Department, Santo Spirito Hospital, Casale Monferrato, Viale Giolitti 2, Italy.
}

Publication history: Received on 28 November 2019; revised on 10 December 2019; accepted on 13 December 2019

Article DOI: https://doi.org/10.30574/gscbps.2019.9.3.0225

\begin{abstract}
Calcifying epithelial odontogenic tumor (CEOT) is an uncommon, benign epithelial odontogenic tumor, first described in 1955 by Pindborg, with a locally aggressive behavior; it represents only 1\% of the total odontogenic tumors. The origin of this locally invasive tumor remains unknown. It is thought to arise from stratum intermedium. It commonly affects the posterior mandible manifesting as a slow-growing asymptomatic swelling, often associated with an impacted tooth. The tumor usually occurs between the second and sixth decade of life and has no gender predilection. In this article we report a case of 73-year-old man with Pindborg tumor localized in lower right gum.
\end{abstract}

Keywords: Calcifying epithelial odontogenic tumor; Pindborg tumor; Rare tumor

\section{Introduction}

Calcifying epithelial odontogenic tumor (CEOT) is a rare and typically benign odontogenic lesion, with most common location in the mandibular premolar and molar region (68\%) and, less frequently, in the maxilla. [1] [2]

CEOT can be divided into two clinico-topographic variants: Intraosseous (central) or Extraosseous (peripheral) with an incidence of $94 \%$ and $6 \%$ respectively. [3]

The term CEOT has been generally accepted and adopted by the WHO in the first edition of "Histological Typing of Odontogenic Tumors, Jaw Cysts, and Alied lesion", where it was recognized as a distinct entity. For more than 30 years the CEOT has been known popularly as the "Pindborg tumor". [4]

Danish pathologist Jens J. Pindborg first described it as a separate entity and he reported three cases, all male patients.

CEOT most commonly occurs in individuals between 20 and 60 years of age with peak incidence in the $5^{\text {th }}$ decade, but a wide age range from 8 to 92 years has been reported.

To date, about 200 cases have been reported, of which only 14 cases occurred in children. [5]

Clinically, CEOT may be found incidentally or it occurs like a slowly growing mass.

Radiologically, the lesion shows radiolucent with variable calcification and can have unilocular or multilocular cystic aspect, simulating an ameloblastoma, a dentigerous cyst, or other odontogenic tumors. [6]

\footnotetext{
${ }^{*}$ Corresponding author

E-mail address: stefania.erra@virgilio.it
}

Copyright (C) 2019 Author(s) retain the copyright of this article. This article is published under the terms of the Creative Commons Attribution Liscense 4.0 
Surgical resection is the treatment of choice. When the resection margins are free of tumor, there is a minimum risk of recurrence; in all cases a follow-up program of the patient is carried out. In the present report, a case of 73-year-old man with Pindborg tumor (CEOT) of gingival is described.

\section{Case report}

A 73-year-old man presented in our hospital for gingival swelling. He performed an orthopantomography showing an irregular mass in the right lower gingiva. Maxillofacial computer tomography (CT) scan revealed the presence of a solid swelling located in the mandibular posterior gum with a diameter of $2.3 \mathrm{~cm}$. In the context of the lesion it have been reported some tenuous calcifications, characterized by modest enhancement, associated with erosion of the cortical profile of the alveolar bone.

A surgical removal was planned for resection of the lesion under general anesthesia. The surgical piece was sent in the surgical pathology laboratory for histological diagnosis. Macroscopically, the lesion was a represented by a $2 \times 1.5 \times 0.8$ $\mathrm{cm}$ neoformation with a whitish area of $1.5 \times 1 \mathrm{~cm}$ (figures 1 ).

The main microscopic features of the tumor were represented by sheets of polyhedral epithelial cells intermingled in a very collagenous connective tissue. The epithelial cells show well-defined cellular borders; a 20X magnification reveals a brilliant eosinophilic cytoplasm and large nuclei. Tumor comprises areas with cementum-like material (figures 2, 3). The lesion is localized in the context of the subepithelial lamina propria, with squamous epithelial lining with anterior and posterior margins free.
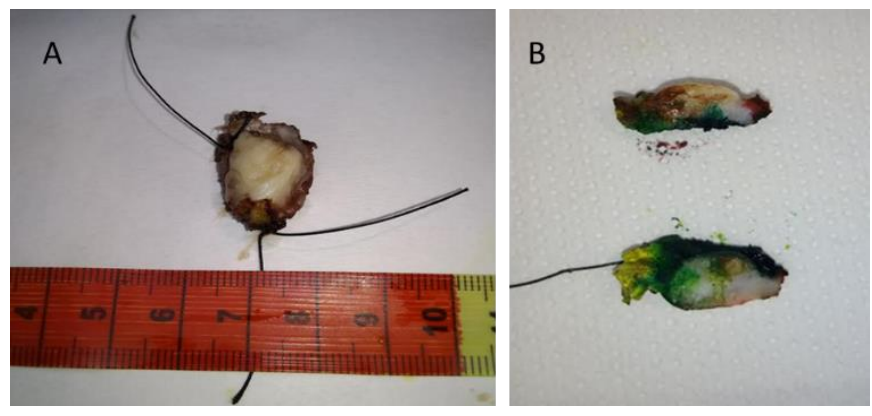

Figures 1 A and B Macroscopically, the lesion shows a well-encapsulated ovoid whitish mass

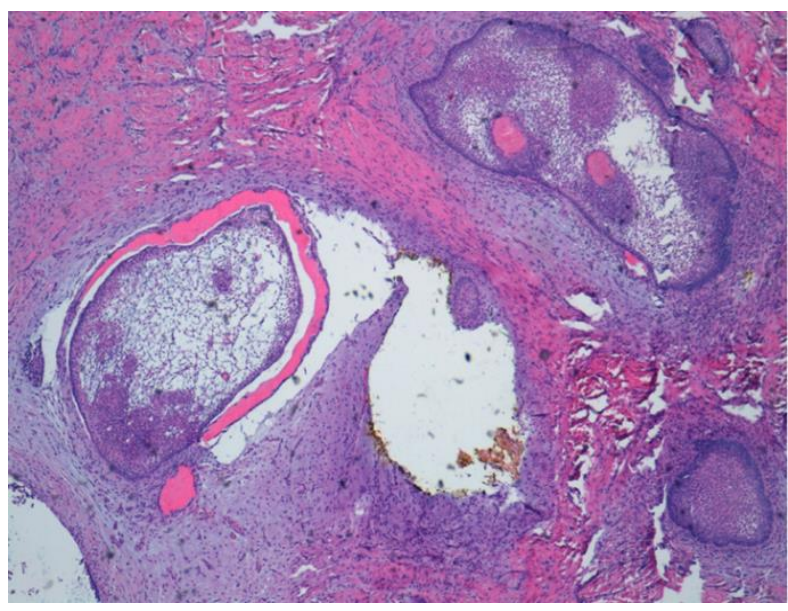

Figure 2 Calcified tumor tissue with central area containing epithelium in the process of calcification (hematoxylineosin, original magnification $4 \mathrm{x}$ ) 


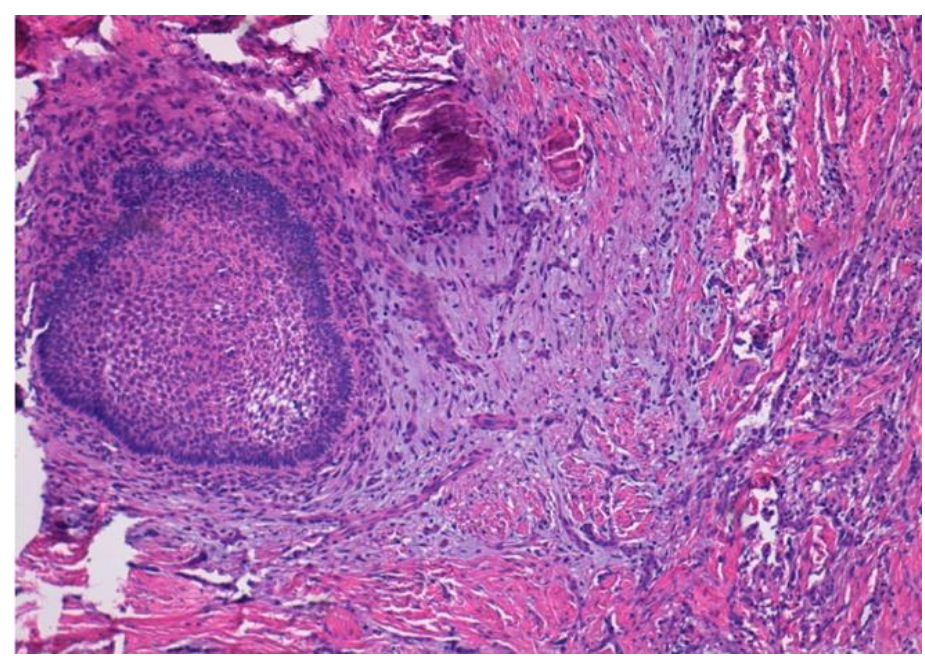

Figure 3 Histopathological picture showing an epithelial odontogenic neoplasm composed of sheets of polyhedral epithelial cells with an abundant eosinophilic, granular cytoplasm and nuclear polymorphism, and irregular calcification. (Magnification 10x).

\section{Discussion}

According to WHO classification of 1992, CEOT is defined as a "locally invasive epithelial neoplasm characterized by the development of intra-epithelial structures, probably of an amyloid-like nature, which may be calcified and which may be liberated as the cells breakdown". [7]

CEOT is often asymptomatic and slow-growing ; however, the presence of symptoms is usually due to the mechanical compression of the tumor on the vital facilities; the lesion may cause pain, epistaxis, headache, nasal obstruction and stuffiness. [8]

Although, CEOT is a benign neoplasm, but on extremely rare occasions can show aggressive growth and features of malignancy. [9]

CEOT histologic picture is typical and includes sheets of polyhedral cells, islands, rows or strands in a scanty connective tissue stroma.

All these features can be observed in the present reported case. [10]

The differential diagnosis of CEOT is based on radiographic evidence, but it must be related to microscopic picture.

The surgical treatment methods can range from simple enucleation or curettage to hemi-mandibulectomy or hemimaxillectomy; the first is recommended for mandibular lesions.

The recurrence rate reported was 10-20\%. [11]

As this particular tumor produce amyloid, patients with Pindborg tumor could be predisposed towards other related amyloid pathologies, such as multiple myeloma as regards malignant neoplasia or systemic manifestations related to amyloid tissue deposits, as glomerulonephritis, vasculitis, dermatitis, neurological and cardiac disorders [12,13].

On the other hand, patients with Pindborg tumors could be genetically investigated, looking for any alterations in the gene coding for transthyretin. This molecule, synthesized in the liver, is involved in the plasma transport of thyroid hormones. A failed or delayed degradation of transthyretin in the bloodstream determines a pathological accumulation, with a consequent tendency to tissue deposition of amyloid proteinaceous material. More than one hundred trasthyretin gene mutations have been detected in patients with familial amyloidosis, but patients with Pindborg tumor aren't subjected to genetic investigation. 


\section{Conclusion}

The CEOT is a rare and benign odontogenic tumor of jaw and maxilla. It still has controversial origin and unpredictable clinical behavior, without a pathognomonic clinical presentation, thereby causing a diagnostic challenge. The key features in diagnosis are its peculiar histological picture and clinico-radiological correlation. Probably detecting possible mutations of the gene coding for transthyretin even in patients with Pindborg tumor could implement the knowledge concerning the interaction between altered protein metabolism and carcinogenesis.

\section{Compliance with ethical standards}

\section{Acknowledgments}

None

\section{Disclosure of conflict of interest}

Authors declare that there are no conflicts of interest in connection with this paper, and the material described is not under publication or consideration for publication elsewhere.

\section{Statement of ethical approval}

The present research work does not contain any studies performed on animals/humans subjects by any of the authors.

\section{Statement of informed consent}

Informed consent was obtained from the patient included in the study.

\section{References}

[1] Gotmare SS, Pereira T, Shetty S and Kesarkar KS. (2018). Pindborg tumor: Pathology with special stains. Indian J Pathol Microbiol, 61(2), 239-241.

[2] Pindborg JJ, Vedtofte P, Reibel J and Praetorius F. (1991). The calcifying epithelial odontogenic tumor. A review of recent literature and report of a case. APMIS Supplement, 23, 152-157.

[3] Vinayakrishna K, Soumithran CS, Sobhana CR and Biradar V. (2013). Peripheral and central aggressive form of Pindborg tumor of mandible - A rare case report. Journal of oral biology and craniofacial research, 3(3), 154158.

[4] Pindborg JJ. (1966). The calcifying epithelial odontogenic tumor. Review of literature and report of an extraosseous case. Acta Odontologica Scandinavica, 24(4), 419-430.

[5] Fazeli SR, Giglou KR, Soliman ML, Ezzat WH, Salama A and Zhao Q. (2019). Calcifying Epithelial Odontogenic (Pindborg) Tumor in a Child: A Case Report and Literature Review. Head and Neck Pathology, 13(4), 580-586.

[6] Veness MJ, Morgan C, Collins AP and Walker DM. (2001). Calcifying epithelial odontogenic (pindborg) tumor with malignant transformation and metastatic spread. Head and Neck Pathology, 23(8), 692-696.

[7] Lim I, Mallari R, Lacsamana N, Paz D and Villafuerte A. (2005). Recurrent calcifying epithelial odontogenic tumor (Pindborg tumor): A case study. Oral Oncology Extra, 41, 259-266.

[8] Maria A, Sharma Y and Malik M. (2010). Calcifying epithelial odontogenic tumour: A case report. Journal Maxillofacial Oral Surgery, 9, 302-306.

[9] Bouckaert MM, Raubenheimer EJ and Jacobs FJ. (2000). Calcifying epithelial odontogenic tumor with intracranial extension: Report of a case and review of the literature. Oral Surgery, Oral Medicine, Oral Pathology, and Oral Radiology, 90(5), 656-662.

[10] Vinod V, Venkateswarlu M and Reddy G. (2011). Pindborg tumor: Review of literature and case reports. Journal of Indian Academy of Oral Medicine and Radiology, 23, 660-663.

[11] Rajendran R and Sivapathasundaram B. (2009). Shafer's Textbook of Oral Pathology. Sixth edition. Elsevier, India, 279-281. 
[12] Kaku M and Berk JL. (2019). Neuropathy Associated with Systemic Amyloidosis, Seminars in Neurology, 39(5), 578-588.

[13] Mankad AK and Shah KB. (2017). Transthyretin Cardiac Amyloidosis. Current Cardiology Reports, 19(10), 97.

\section{How to cite this article}

Stefania E, Valentina C, Michele DL, Alessia F and Luca Z. (2019). A 73-year-old man with pindborg tumor: A case report. GSC Biological and Pharmaceutical Sciences, 9(3), 47-51. 